\title{
Area Postrema Neurons Are Modulated by the Adipocyte Hormone Adiponectin
}

\author{
Mark Fry, ${ }^{1}$ Pauline M. Smith, ${ }^{1}$ Ted D. Hoyda, ${ }^{1}$ Marnie Duncan, ${ }^{2}$ Rexford S. Ahima, ${ }^{3}$ Keith A. Sharkey, ${ }^{2}$ and \\ Alastair V. Ferguson ${ }^{1}$ \\ ${ }^{1}$ Department of Physiology, Queen's University, Kingston, Ontario, Canada, K7L 3N6, 2Department of Physiology and Biophysics, University of Calgary, \\ Calgary, Alberta, Canada, T2N 4N1, and ${ }^{3}$ Division of Endocrinology, Diabetes, and Metabolism, Department of Medicine, University of Pennsylvania School \\ of Medicine, Philadelphia, Pennsylvania 19104
}

\begin{abstract}
Adiponectin is an adipocyte-derived peptide hormone involved in energy homeostasis and the pathogenesis of obesity, including hypertension. Area postrema (AP) lacks a blood-brain barrier and is a critical homeostatic integration center for humoral and neural signals. Here we investigate the role of AP in adiponectin signaling. We show that rat AP expresses AdipoR1 and AdipoR2 adiponectin receptor mRNA. We used current-clamp electrophysiology to investigate whether adiponectin influenced membrane properties of AP neurons and found that $\sim 60 \%$ of rat AP neurons tested were sensitive to adiponectin. Additional electrophysiology experiments coupled with single-cell reverse transcription-PCR indicated that all neurons that expressed both subtypes of receptor were sensitive to adiponectin, whereas neurons expressing only one subtype were predominantly insensitive. Last, microinjection of adiponectin into AP caused significant increases in arterial blood pressure, with no change in heart rate, suggesting that adiponectin acts at AP to provide a possible link between control of energy homeostasis and cardiovascular function.
\end{abstract}

Key words: adiponectin; area postrema; circumventricular organ; patch clamp; microinjection; homeostasis

\section{Introduction}

Obesity is associated with development of insulin resistance, diabetes, cardiovascular disease, and hypertension, but the basis of these associations is presently unclear. It is now recognized that adipose tissue is also an important endocrine organ producing hormones with immune, cardiovascular, metabolic, and endocrine functions (Prins, 2002). Adiponectin is a fat cell-derived hormone thought to act as an insulin-sensitizing hormone and is downregulated with obesity-related diseases, such as insulin resistance and metabolic syndrome (Scherer et al., 1995; Kadowaki and Yamauchi, 2005). Treatment with adiponectin lowers hepatic gluconeogenesis, lowers serum glucose, and ameliorates insulin resistance in mice (Berg et al., 2001; Combs et al., 2001; Yamauchi et al., 2001; Kadowaki and Yamauchi, 2005). Transgenic mice overexpressing adiponectin demonstrate increased fatty acid clearance and insulin sensitivity (Combs et al., 2004). Conversely, adiponectin knock-out mice demonstrate obesity, impaired insulin sensitivity, impaired fatty acid clearance, and hypertension (Kubota et al., 2002; Maeda et al., 2002). Human

Received May 10, 2006; revised Aug. 9, 2006; accepted Aug. 9, 2006.

This work was supported by a grant from Heart and Stroke Foundation of Ontario (A.V.F.), a New Emerging Team grant from Canadian Institutes of Health Research (CIHR) (A.V.F., K.A.S.), and National Institutes of Health Grant P01-DK49210 (R.S.A.). M.F. holds a Target Obesity postdoctoral fellowship (CIHR/Canadian Heart and Stroke Foundation/Canadian Diabetes Association). M.D. is an Alberta Heritage Foundation for Medical Research (AHFMR) and Canadian Association of Gastroenterology/Janssen-Ortho/CIHR Postdoctoral Fellow. K.A.S. is an AHFMR Medical Scientist and Crohn's and Colitis Foundation of Canada Chair in Inflammatory Bowel Disease Research.

Correspondence should be addressed to Alastair Ferguson, Department of Physiology, Faculty of Life Sciences, Queen's University, Kingston, Ontario, Canada, K7L 3N6. E-mail: avf@post.queensu.ca.

DOI:10.1523/JNEUROSCI.2014-06.2006

Copyright $\odot 2006$ Society for Neuroscience $\quad$ 0270-6474/06/269695-08\$15.00/0 genetic studies indicate that alterations in adiponectin signaling may increase susceptibility to obesity, insulin resistance, diabetes, and hypertension (Kondo et al., 2002; Ukkola and Santaniemi, 2002; Iwashima et al., 2004; Damcott et al., 2005; Hara et al., 2005; Kadowaki and Yamauchi, 2005).

Qi et al. (2004) demonstrated that injection of adiponectin into the cerebral ventricles of mice caused changes in glucose, lipids, and body weight similar to those produced by peripheral injection, implicating the brain as a target for adiponectin. More recently, Jung et al. (2006) demonstrated that adiponectin acts on neuroblastoma cells. Although adiponectin receptors (AdipoR) are expressed in the CNS (Qi et al., 2004), no specific sites of action for adiponectin have been identified. Moreover, circulating adiponectin does not appear to cross the blood-brain barrier (BBB) (Pan et al., 2006; Spranger et al., 2006). The sensory circumventricular organs (CVOs), specifically the organum vasculosum of the lamina terminalis, the subfornical organ, and the area postrema (AP), lack the $\mathrm{BBB}$, which is present throughout most of the brain. Therefore, the neurons found in the sensory CVOs are in direct contact with substances and hormones in the blood and act as transducers of circulating signals from the blood into the CNS. Neurons of the sensory CVOs are thus potential sites within the CNS in which adiponectin could act to exert central effects.

The AP, a medullary CVO, is uniquely positioned to monitor and regulate physiological processes. AP neurons are responsive to a number of circulating peptide hormones, including those involved in energy homeostasis, such as cholecystokinin, orexin-A, amylin, and ghrelin, and those involved in the regulation of blood pressure, such as atrial natriuretic peptide, angio- 
tensin, and vasopressin (McKinley et al., 2003; Cottrell and Ferguson, 2004). AP neurons integrate hormonal and neural signals and project to centers involved in homeostatic control, including nucleus of the solitary tract, rostral ventrolateral medulla, lateral parabrachial nucleus, and lateral hypothalamus (Ferguson, 1991; Bishop and Hay, 1993; McKinley et al., 2003). Therefore, we investigated whether adiponectin receptors were present on AP neurons, whether adiponectin influenced AP neurons, and whether there were physiological consequences of the actions by adiponectin on AP neurons.

\section{Materials and Methods}

Cell culture. All animal protocols conformed to the standards of the Canadian Council on Animal Care and the Queen's University Animal Care Committee. Cell cultures were prepared according to protocols modified from Brewer (1997). Briefly, three to four rats were decapitated, and the brains were quickly removed and placed into oxygenated, icecold artificial CSF containing the following (in mM): $124 \mathrm{NaCl}, 2 \mathrm{KCl}$, $1.25 \mathrm{KH}_{2} \mathrm{PO}_{4}, 2.0 \mathrm{CaCl}_{2}, 1.3 \mathrm{MgSO}_{4}, 20 \mathrm{NaHCO}_{3}$, and 10 glucose. Brainstem slices were cut $(300 \mu \mathrm{m})$ and transferred into Hibernate media (Brain Bits, Springfield, IL) supplemented with $1 \times$ B27 supplement (Invitrogen, Burlington, Ontario, Canada). AP was dissected away from surrounding tissue, transferred to $5 \mathrm{ml}$ Hibernate media containing 10 mg of papain (Worthington, Lakewood, NJ), and incubated at $30^{\circ} \mathrm{C}$ for $30 \mathrm{~min}$. AP tissue was then washed in Hibernate media/B27, triturated, centrifuged at $100 \times g$ for $2 \mathrm{~min}$, and resuspended in Neurobasal-A/B27 (Invitrogen). The dissociated neurons were then plated on uncoated glass-bottom dishes (MatTek Ashland, MA) at a low density ( $\sim 10$ cells/ $\mathrm{mm}^{2}$, to ensure synaptic contacts did not form between cells) and incubated at $37^{\circ} \mathrm{C}$ in $5 \% \mathrm{CO}_{2}$. Neurons prepared in this manner could survive for at least 2 weeks, but electrophysiological experiments were performed within 1-4 d, with no noticeable differences during this period. During this time, many neurons sprouted a few short $(<5 \mu \mathrm{m})$ neurites, but functional synaptic contacts between neurons were never observed.

Electrophysiology. Whole-cell current-clamp recordings from AP neurons were made using an Axopatch 200B or 700B patch-clamp amplifier (Molecular Devices, Palo Alto, CA). Stimulation and recording were controlled by Spike2 version 4/5 software (Cambridge Electronics Design, Cambridge, UK). Data were filtered at $1 \mathrm{kHz}$ and acquired at $8 \mathrm{kHz}$, digitized using a Cambridge Electronics Design Micro1401 interface. Some data were also collected using a Heka Elektronik (Halifax, Nova Scotia, Canada) EPC10 with Patchmaster software. Capacitive transients and series resistance errors were minimized before recording. For all recordings, the external recording solution contained the following (in $\mathrm{mm}$ ): $140 \mathrm{NaCl}, 5 \mathrm{KCl}, 1 \mathrm{MgCl}_{2}, 2 \mathrm{CaCl}_{2}, 10$ HEPES, and 10 glucose, $\mathrm{pH}$ 7.3 with $\mathrm{NaOH}$. Patch electrodes were fabricated from borosilicate glass (World Precision Instruments, Sarasota FL) and had resistances of 2.5-5 $\mathrm{M} \Omega$ when filled with internal recording solution (in $\mathrm{mM}$ ): 130 K-gluconate, $10 \mathrm{KCl}, 1 \mathrm{MgCl}_{2}, 2 \mathrm{CaCl}_{2}, 10 \mathrm{HEPES}, 10$ EGTA $4 \mathrm{Na}_{2} \mathrm{ATP}$, and 0.1 GTP. All chemicals were purchased from Sigma (Oakville, Ontario, Canada).

Analysis of electrophysiology data. Responsiveness of AP neurons was determined by comparing membrane potential of neurons before and after perfusion of the dish with external recording solution containing $1 \times 10^{-8}$ to $1 \times 10^{-12} \mathrm{M}$ adiponectin (Phoenix Pharmaceuticals, Bellmont, CA). AP neurons were considered responsive if their mean membrane potential demonstrated a shift of at least $4.5 \mathrm{mV}$ (over a $100 \mathrm{~s}$ period) during the $300 \mathrm{~s}$ after bath perfusion compared with the $100 \mathrm{~s}$ before application. This value for a "response threshold" was chosen as follows: membrane potential from five AP neurons was measured before and after application of collagen-like $\mathrm{N}$-terminal fragment of adiponectin control peptide (Phoenix Pharmaceuticals), which has been reported to be inactive (Qi et al., 2004). There was no observable response in these cells, and the SD of the digitized membrane potential data (over a $100 \mathrm{~s}$ period) was at most $2.25 \mathrm{mV}$. Two times this SD therefore provided a conservative threshold value for distinguishing responding and nonresponding cells. Alternatively, in the few cells exhibiting regular highfrequency spontaneous action potentials $(>4 \mathrm{~Hz})$, a cell was considered responsive if it exhibited a change of at least $1 \mathrm{~Hz}$ (in a $100 \mathrm{~s}$ period) during the $300 \mathrm{~s}$ after bath perfusion.

Cells in which adiponectin induced a depolarization large enough to cause inactivation of voltage-gated $\mathrm{Na}^{+}$channels (and a decrease in action potential frequency) and quiescent cells in which adiponectin induced a hyperpolarization were not used for calculation of changes in mean frequency.

Statistical analyses were performed using Origin 7.0 (Microcal Software, Northampton, MA) and GraphPad (San Diego, CA) Prism 4.0. Kruskal-Wallis nonparametric ANOVA was used in instances in which the assumption of normality was inappropriate.

Reverse-transcription-PCR. AP tissue was isolated from brainstem slices as described above, and total RNA was extracted using Trizol (Invitrogen) according to the directions of the manufacturer directions. Approximately one-quarter of the total RNA from the AP of a single rat was used as template to synthesize oligo-dT primed cDNA in a $20 \mu \mathrm{l}$ reaction with the Retroscript cDNA synthesis kit (Ambion, Austin, TX) according to the directions of the manufacturer. One microliter of this cDNA was used as template for a standard PCR. Each reaction was performed under the following conditions: $1 \times$ PCR buffer, $0.2 \mathrm{~mm}$ each dNTP, $1.5 \mathrm{~mm} \mathrm{MgCl}_{2}, 0.2 \mu \mathrm{m}$ each primer (Table 1), $1 \mathrm{U}$ of Platinum Taq (Invitrogen), and $1 \mu \mathrm{l}$ of AP cDNA template. The reactions were cycled in an Eppendorf (Westbury, NY) Mastercycler as follows: initial denaturation at $94^{\circ} \mathrm{C}$ for $3 \mathrm{~min}, 35$ cycles of $94^{\circ} \mathrm{C}$ for $30 \mathrm{~s}, 55^{\circ} \mathrm{C}$ for $30 \mathrm{~s} 72^{\circ} \mathrm{C}$ for $60 \mathrm{~s}$, and a final extension at $72^{\circ} \mathrm{C}$ for $45 \mathrm{~s}$ for $5 \mathrm{~min}$. PCR products were electrophoresed on a $2 \%$ agarose gel and sequenced to confirm identity (Robarts, London, Ontario, Canada).

Localization of adiponectin receptors by in situ hybridization. Male Sprague Dawley rats (250-300 g) were anesthetized with sodium pentobarbital and perfused transcardially with PBS prepared with diethylpyrocarbonate (DEPC)-treated water, followed by $10 \%$ neutral buffered Formalin. Brains were removed, immersed in the same fixative overnight, and then cryoprotected in $20 \%$ sucrose in PBS-diethylpyrocarbonate at $4^{\circ} \mathrm{C}$. Five series of $20 \mu \mathrm{m}$ coronal sections were cut on a Reichert cryotome, mounted on Superfrost Plus glass slides (Fisher Scientific, Houston, TX), air dried, and stored in desiccated boxes at $-20^{\circ} \mathrm{C}$. Before hybridization, sections were fixed in $4 \%$ formaldehyde in DEPC-treated PBS, pH 7.0, for $20 \mathrm{~min}$ at $4^{\circ} \mathrm{C}$, dehydrated in increasing concentrations of ethanol, cleared in xylene for $15 \mathrm{~min}$, rehydrated in decreasing concentrations of ethanol, placed in prewarmed sodium citrate buffer $\left(95-100^{\circ} \mathrm{C}, \mathrm{pH} 6.0\right)$, and then dehydrated in ethanol and air dried. Riboprobes for AdipoR1 and AdipoR2 were generated using primers described previously (Yamauchi et al., 2003), and in situ hybridization was performed (Ahima et al., 1999; Kelly et al., 2004). The ${ }^{35}$ S-labeled antisense cRNA probes were diluted to $10^{6} \mathrm{cpm} / \mathrm{ml}$ in a hybridization solution containing $50 \%$ formamide, $10 \mathrm{~mm}$ Tris- $\mathrm{HCl}, \mathrm{pH}$ 8.0, $5.0 \mathrm{mg}$ of tRNA (Invitrogen), $10 \mathrm{~mm}$ dithiothreitol (DTT), 10\% dextran sulfate, $0.3 \mathrm{M} \mathrm{NaCl}, 1 \mathrm{~mm}$ EDTA, pH 
8.0, and $1 \times$ Denhardt's solution. The slides were incubated at $57^{\circ} \mathrm{C}$ for 12-16 $\mathrm{h}$, coverslips were removed, and the sections were then washed with $2 \times$ SSC buffer and incubated in $0.002 \%$ RNase A (Roche Molecular Biochemicals, Indianapolis, IN) with $0.5 \mathrm{~m} \mathrm{NaCl}, 10 \mathrm{~mm}$ Tris- $\mathrm{HCl}, \mathrm{pH}$ 8.0, and $1 \mathrm{~mm}$ EDTA for $30 \mathrm{~min}$, followed by a $30 \mathrm{~min}$ incubation in the same buffer minus the RNase. The sections were then washed in $2 \times$ SSC, $0.25 \%$ DTT at $50^{\circ} \mathrm{C}$ for $1 \mathrm{~h}, 0.2 \times$ SSC, $0.25 \%$ DTT at $55^{\circ} \mathrm{C}$ for $1 \mathrm{~h}, 0.2 \times$ SSC, $0.25 \%$ DTT at $60^{\circ} \mathrm{C}$ for $1 \mathrm{~h}$, and then dehydrated in increasing concentrations of ethanol containing $0.3 \mathrm{M}$ ammonium acetate, followed by $100 \%$ ethanol. Slides were air dried and placed in X-ray film cassettes with BMR-2 film (Eastman Kodak, Rochester, NY) for $3 \mathrm{~d}$ and subsequently dipped in NTB2 photographic emulsion (Eastman Kodak), dried, and stored in desiccated, foil-wrapped boxes at $4^{\circ} \mathrm{C}$ for $2-3$ weeks, after which they were developed with D-19 developer (Eastman Kodak), counterstained with thionin, dehydrated in graded ethanols, cleared in xylene, and coverslipped with Permount (Fisher Scientific). The specificity of AdipoR1 and AdipoR2 was verified using sense probes, as well as treatment of some sections with RNase A, followed by antisense probes. These control experiments showed no evidence of nonspecific labeling. The slides were examined with a Nikon (Tokyo, Japan) E600 microscope, and dark-field photomicrographs were taken with a SPOT RT digital camera (Phase 3 Imaging Systems, Glen Mills, PA).

Single-cell reverse transcription-PCR. Some cells were used for singlecell reverse transcription (RT)-PCR to correlate expression of the AdipoR1 and AdipoR2 and electrophysiological responses to adiponectin. Patch clamp was performed using electrodes (as above) that had been baked for at least $1.5 \mathrm{~h}$ at $200^{\circ} \mathrm{C}$ and filled with $6 \mu \mathrm{l}$ of internal solution (prepared with RNase-free reagents). cDNA was synthesized from single cells using the Cells Direct kit (Invitrogen) as per the directions. Briefly, after electrophysiological recording, the contents of the cell were harvested by negative suction and expelled into a $0.5 \mathrm{ml}$ centrifuge tube containing $5 \mu \mathrm{l}$ of resuspension buffer, $1 \mu \mathrm{l}$ of lysis enhancer, and $0.5 \mu \mathrm{l}$ RNase inhibitor. The tube was heated to $75^{\circ} \mathrm{C}$ for $10 \mathrm{~min}$, briefly centrifuged, and placed on ice, and $2.5 \mu \mathrm{l}$ of DNase I and $0.8 \mu \mathrm{l}$ of DNase buffer were added. The tube was incubated at room temperature for $5 \mathrm{~min}$, and $0.6 \mu \mathrm{l}$ of $25 \mathrm{~mm}$ EDTA was added. The tube was then incubated at $70^{\circ} \mathrm{C}$ for $5 \mathrm{~min}$, and cDNA was synthesized in a $30 \mu \mathrm{l}$ reaction (as per the directions of the kit), including $16 \mathrm{~nm}$ of a modified oligo-dT primer (Table 1). After synthesis, the cDNA was preamplified using a modification of the $3^{\prime}$ end amplification technique (Dixon et al., 1998). Briefly, 30 $\mu \mathrm{l}$ of first-round preamplification PCR mix (containing $1 \times$ PCR buffer, $3 \mathrm{~mm} \mathrm{MgCl}_{2}, 3.5 \mathrm{~mm}$ each dNTP, $10 \mathrm{~nm}$ second-strand primer, $10 \mathrm{~nm}$ heel primer, and $2.5 \mathrm{U}$ of Platinum Taq) were added to the $30 \mu \mathrm{l}$ of cDNA, and the reaction was cycled as follows: initial cycle of $94^{\circ} \mathrm{C}$ for $3 \mathrm{~min}, 50^{\circ} \mathrm{C}$ for $15 \mathrm{~min}, 72^{\circ} \mathrm{C}$ for $10 \mathrm{~min}, 94^{\circ} \mathrm{C}$ for $2 \mathrm{~min}, 15$ cycles of $94^{\circ} \mathrm{C}$ for $1 \mathrm{~min}, 60^{\circ} \mathrm{C}$ for $1.5 \mathrm{~min}, 72^{\circ} \mathrm{C}$ for $1.5 \mathrm{~min}$, and a final extension at $72^{\circ} \mathrm{C}$ for $10 \mathrm{~min}$. After this, $30 \mu \mathrm{l}$ of second-round preamplification mix (containing $1 \times$ PCR buffer, $3 \mathrm{~mm} \mathrm{MgCl} 2$, $3.5 \mathrm{~mm}$ each dNTP, $0.2 \mu \mathrm{m}$ second-strand primer, $0.2 \mu \mathrm{M}$ heel primer, and $2.5 \mathrm{U}$ of Platinum Taq) were added, and cycled as above but for 25 cycles. This amplified cDNA was used as template for RT-PCR using conditions and cycling parameters identical to those used for standard RT-PCR, except that 40 cycles were performed.

Several control reactions were included with every experiment to eliminate the possibility of false-positive and false-negative results. As a negative control, a "bath solution" control included $5 \mu$ l of circulating external recording solution (instead of a harvested cell) in a cDNA synthesis reaction. An "RT minus" control, consisted of a mock cDNA synthesis reaction performed using a harvested cell, but the reverse transcriptase enzyme was omitted from the reaction. We also performed "notemplate" controls for each of the PCR reactions. Negative control reactions did not produce PCR products. We also included, as a positive control, cDNA synthesis reactions using dilute whole AP RNA.

Microinjection. Urethane-anesthetized $(1.4 \mathrm{~g} / \mathrm{kg})$ male Sprague Dawley rats (150-350 g; Charles River Laboratories, Wilmington, MA) were fitted with a tracheal cannula (PE-205; Intramedic) to facilitate breathing and a femoral arterial catheter for the measurement of blood pressure and heart rate. The animal was placed on a feedback-controlled heating blanket to maintained body temperature at $37^{\circ} \mathrm{C}$. The animal was then placed in a stereotaxic frame with its head positioned vertically (nose down), and a midline incision was made to expose the dorsal medulla, such that a microinjection cannula (150 $\mu \mathrm{m}$ tip diameter; Rhodes Medical Instruments, Woodland Hills, CA) could be positioned into the AP. After a minimum 2 min stable baseline recording was obtained, adiponectin or control peptide [inactive collagen-like $\mathrm{N}$-terminal adiponectin fragment (Qi et al., 2004)] was microinjected into the region, and the effects on blood pressure and heart rate assessed. Circulating concentrations of adiponectin in male Sprague Dawley rats is $\sim 3 \mu \mathrm{g} / \mathrm{ml}(100 \mathrm{~nm})$ (Yang et al., 2004). To achieve saturation in AP, we chose to microinject $500 \mathrm{nl}$ of $2 \mu \mathrm{M}$ adiponectin or control peptide. This volume was chosen based on previous work demonstrating that $500 \mathrm{nl}$ is a volume of vehicle that reaches a maximum number of neurons within the AP while still remaining localized to the $\mathrm{AP}$, i.e., this volume fails to spread into adjacent areas or leak from AP into circulation (Lowes et al., 1993). Experiments performed using microinjected dye and fluorogold confirm the suitability of this volume of injectate (our unpublished observations).

At the end of the experiment, animals were overdosed with anesthetic and perfused with $0.9 \%$ saline, followed by $10 \%$ formalin, through the left ventricle of the heart. The brain was removed and placed in Formalin for at least $24 \mathrm{~h}$. Using a vibratome, $50 \mu \mathrm{m}$ coronal sections were cut through the region of AP mounted and cresyl violet stained. The anatomical location of the microinjection site was verified at the light microscope level by an observer unaware of the experimental protocol or the data obtained.

Analysis of blood pressure and heart rate data. Animals that were determined to have microinjection sites within the anatomical boundaries of AP were placed into one of two groups according to whether adiponectin or the control peptide was microinjected. Normalized blood pressure and heart rate data (mean baseline blood pressure and heart rate data were calculated for $60 \mathrm{~s}$ before injection and subtracted from all data points before and after injection) were obtained for each animal $60 \mathrm{~s}$ before the time of microinjection (control period) until $50 \mathrm{~s}$ after microinjection. Area under the curve (AUC) (area between baseline and each blood pressure and heart rate response) was calculated for each animal for the $300 \mathrm{~s}$ time period immediately after the injection, and the mean AUC was then calculated for both the adiponectin and control peptide groups. A Student's $t$ test was used to determine whether blood pressure and heart rate responses observed in response to adiponectin were different from those seen in response to control peptide.

\section{Results}

\section{AdipoR1 and AdipoR2 are expressed in area postrema}

To investigate a potential role of AP in central adiponectin signaling, we initially set out to determine whether adiponectin receptors AdipoR1 and AdipoR2 are expressed in rat AP. We first performed RT-PCR using cDNA synthesized from acutely dissected AP tissue and primers specific for AdipoR1 and AdipoR2 (Table 1, Fig. 1A). We detected mRNA encoding both receptor subtypes in AP, indicating that both receptor subtypes are expressed in this brain region. We next performed in situ hybridizations to confirm that AdipoR1 and AdiporR2 were expressed in AP (Fig. $1 B$ ). Although not quantitative, these data revealed that mRNA for both receptors was strongly expressed in AP, suggesting a role for AP in detection of circulating adiponectin.

\section{Adiponectin directly affects AP neurons}

To investigate the mechanism by which adiponectin acts in AP, we performed current-clamp electrophysiological recordings from neurons maintained in culture for $1-4 \mathrm{~d}$ and examined the effect of exogenously applied adiponectin. AP neurons were visually identified as being phase bright, $6-10 \mu \mathrm{m}$ in diameter, and often having one or more short primary neurites. Neurons in contact with other cells in the culture were not used for analysis. A total of 72 neurons were recorded (mean input resistance of $2.12 \pm 0.16 \mathrm{G} \Omega ; n=59$ ). Forty six percent of these neurons 
A

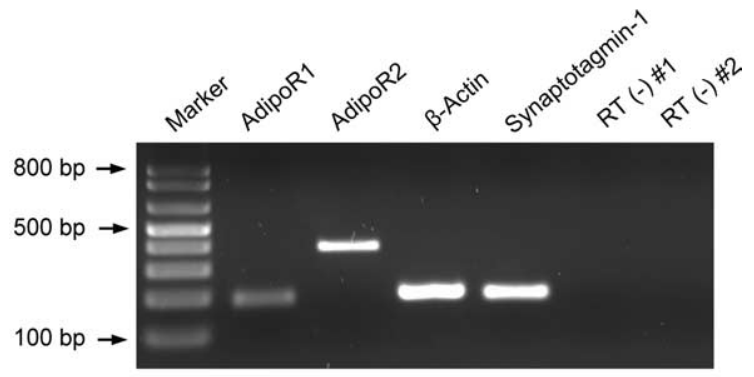

B
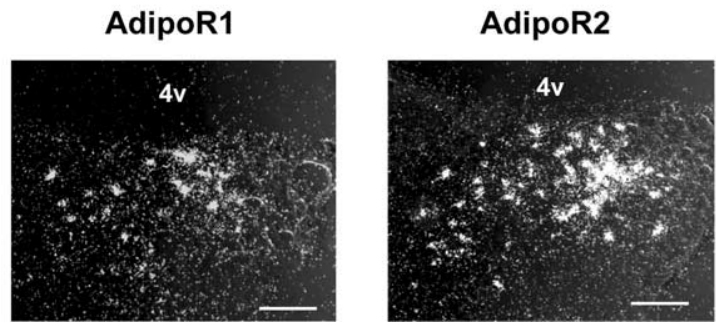

Figure 1. Expression of adiponectin receptor mRNA in AP. A, Agarose gel showing RT-PCR analysis of AP CDNA using primers specific for the receptors AdipoR1 and AdipoR2 and the housekeeping genes $\beta$-actin and synaptotagmin-1. No PCR products were observed in the two RT minus control reactions in which reverse transcriptase enzyme was omitted from the CDNA synthesis reaction: lane marked RT (-) \#1 used primers for $\beta$-actin; lane marked RT ( - ) \#2 used primers for synaptotagmin-1. B, Dark-field photomicrographs of in situ hybridization with probes specific for AdipoR1 and AdipoR2, demonstrating mRNA expression in the AP. 4v, Fourth ventricle. Scale bars, $50 \mu \mathrm{m}$.

displayed spontaneous activity with a mean frequency of $1.37 \pm$ $0.35 \mathrm{~Hz}$.

Globular adiponectin (10 nM) was applied by bath perfusion to 49 neurons in total. Using established criteria (see Materials and Methods), 59\% (29 of 49) of the cells tested were responsive, showing changes in membrane potential of at least $4.5 \mathrm{mV}$ or changes in frequency of at least $1 \mathrm{~Hz}$. Of these responsive cells, $66 \%$ (19 of 29) exhibited a depolarization of membrane potential (mean of $12.2 \pm 1.8 \mathrm{mV}$ ), and the remaining $34 \%$ (10 of 29) exhibited a hyperpolarization (mean of $-7.5 \pm 1.3 \mathrm{mV}$ ), as illustrated in Figures $2 A-C$ and $3 A$. These changes in membrane potential were usually accompanied by predictable changes in spontaneous action potential frequency (Fig. 3B): neurons that depolarized exhibited a mean increase of $1.50 \pm 0.71 \mathrm{~Hz}$ in spontaneous activity, and those that hyperpolarized exhibited a mean decrease of $0.29 \pm 0.14 \mathrm{~Hz}$. The mean changes in action potential frequency were determined to be significantly different between all groups using the Kruskal-Wallis nonparametric ANOVA $(p=$ $0.001 ; n=40$ ), followed by Dunn's multiple comparison test.

Over the range of $10 \mathrm{~nm}$ to $1 \mathrm{pm}$, the effect of adiponectin on AP neuron membrane potential displayed concentration dependence (Fig. 3C). At $10 \mathrm{~nm}, 59 \%$ of cells exhibited a response, whereas this decreased to $38 \%$ ( 5 of 13 ) at $1 \mathrm{~nm}, 12.5 \%$ ( 1 of 8 ) at $100 \mathrm{pm}, 25 \%$ ( 1 of 4 ) at $10 \mathrm{pm}$, and $0 \%(0$ of 8 ) at 1 pm (Fig. $3 C$ ). In addition, the mean change in membrane potential induced by adiponectin also decreased over this range of concentrations (Fig. 3D).

To confirm that the effects of adiponectin on membrane potential and activity in AP neurons is not restricted to neurons in culture, we performed current-clamp experiments on AP neurons from acutely isolated brainstem slices. Recordings from seven AP neurons revealed that six were sensitive to adiponectin, with five exhibiting depolarization $(5.7 \pm 1.6 \mathrm{mV})$ and one ex-

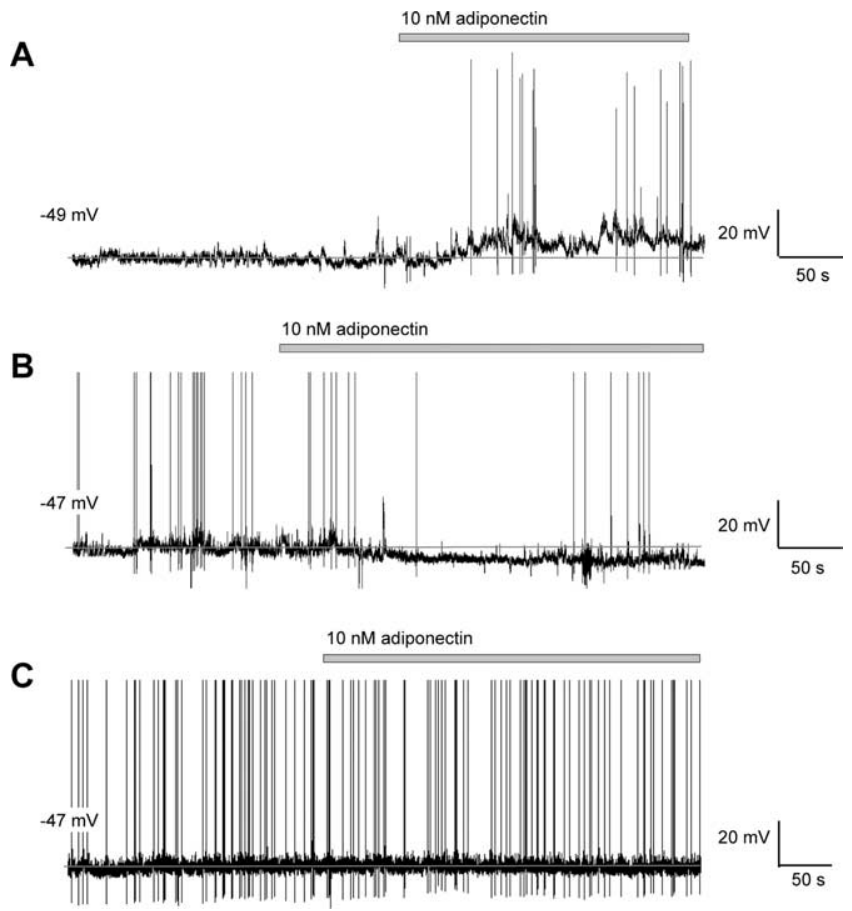

Figure 2. Adiponectin directly affects AP neurons. Representative current-clamp recordings of AP neurons that were depolarized $(\boldsymbol{A})$, hyperpolarized $(\boldsymbol{B})$, or unaffected $(\boldsymbol{C})$ by application of $10 \mathrm{~nm}$ adiponectin (light gray bar).
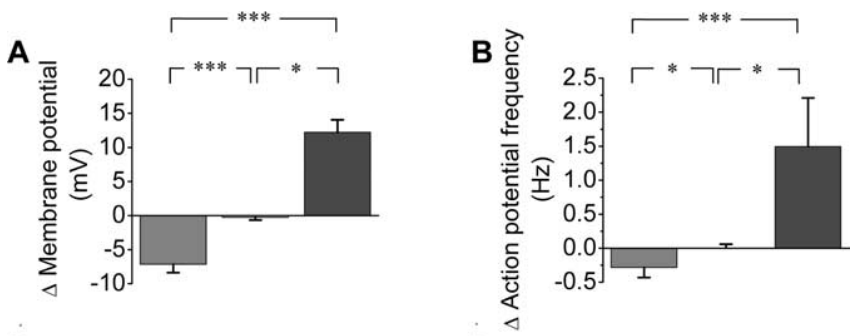

C

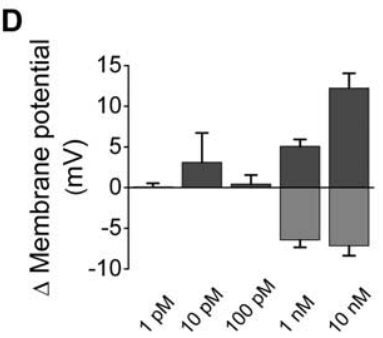

Figure 3. $\quad \boldsymbol{A}, \boldsymbol{B}, \mathrm{Bar}$ graphs representing mean changes in membrane potential $(\boldsymbol{A})$ and action potential frequency $(\boldsymbol{B})$ for cells treated with $10 \mathrm{~nm}$ adiponectin. The mean changes in action potential frequency were significantly different between all groups using the Kruskal-Wallis nonparametric ANOVA $[p<0.001 ; n=4,20$, and 16 for cells that hyperpolarize (left), do not respond (middle), and depolarize (right), respectively]. Neurons in which action potential activity was abolished by inactivation of $\mathrm{Na}^{+}$channels attributable to membrane depolarization $>10 \mathrm{mV}$ or that were quiescent before hyperpolarization were not included in the analysis. ${ }^{*} p<0.05 ;{ }^{* * *} p<0.001$. C, D, Bar graphs showing that effect of adiponectin on membrane potential was dose related: application of decreasing concentrations of adiponectin caused a decrease in the percentage of cells responding $(C)$ and the amplitude of the membrane potential responses of the responding cells $(\boldsymbol{D})$. For concentrations 1-100 pM, there were no hyperpolarizing responses, and therefore mean change in membrane potential was calculated using all cells.

hibiting hyperpolarization $(-3.5 \mathrm{mV})$ on application of $10 \mathrm{nM}$ adiponectin. Together, these results indicated that AP neurons maintained in culture and from acutely prepared slices both exhibit sensitivity to adiponectin. 

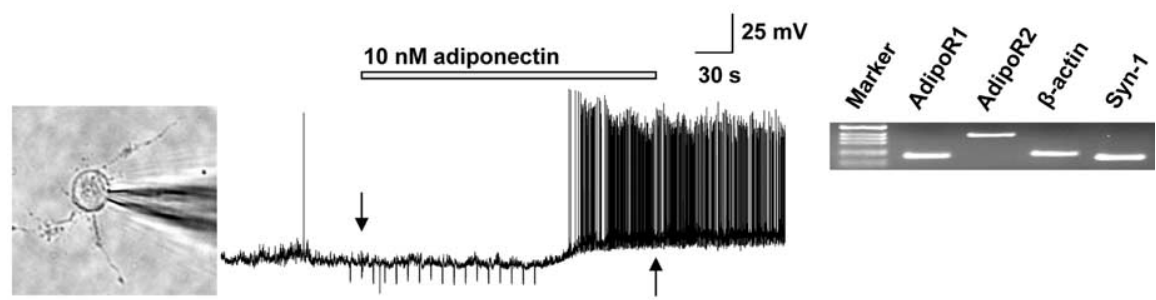

D

\begin{tabular}{c|cccc}
\hline \multirow{2}{*}{$\begin{array}{c}14 \text { AP neurons } \\
\text { tested for } \\
\text { sensitivity to } \\
\text { Adiponectin }\end{array}$} & \begin{tabular}{c} 
Both \\
\cline { 2 - 5 }
\end{tabular} & $\begin{array}{c}\text { AdipoR1/AdipoR2 } \\
\text { Oene expression profile in single AP neurons }\end{array}$ \\
\hline $\begin{array}{c}\text { Responsive } \\
(n=8)\end{array}$ & $7 / 8$ & $0 / 8$ & Only AdipoR2 & $\begin{array}{c}\text { Neither } \\
\text { AdipoR1/AdipoR2 }\end{array}$ \\
\hline $\begin{array}{c}\text { Non Responsive } \\
(n=6)\end{array}$ & $0 / 6$ & $4 / 6$ & $1 / 8$ & $0 / 8$ \\
\hline
\end{tabular}

Figure 4. Analysis of AdipoR1 and AdipoR2 expression in single neurons. $A$, Example of a neuron that was been maintained in culture and subjected to patch clamp, followed by RT-PCR analysis. $\boldsymbol{B}$, Example of a current-clamp recording from a neuron that responded to $10 \mathrm{~nm}$ adiponectin (bar). Note that the hyperpolarizing voltage deflections elicited in response to $10 \mathrm{pA}$ current injection (commencing early during adiponectin application, indicated by downward arrow) were not observed as the cell fired spontaneous action potentials (recommencing at time indicated by upward arrow), indicating a large decrease in input resistance for this cell. $\boldsymbol{C}$, Agarose gel of single-cell RT-PCR products from the cell in $\boldsymbol{B}$, indicating that this cell expressed both AdipoR1 and AdipoR2, in addition to the housekeeping genes $\beta$-actin and synaptotagmin-1 (Syn-1). $\boldsymbol{D}$, Correlation of the sensitivity of AP neurons to $10 \mathrm{~nm}$ adiponectin (left) with the expression profile of AdipoR1 and AdipoR2 mRNA (right). Lanes of agarose gels indicate single-cell RT-PCR products for AdipoR1, AdipoR2, $\beta$-actin, and synaptotagmin-1 (as in part above; see $C$ ) and represent expression profile. Of the $14 \mathrm{AP}$ neurons tested, eight responded to $10 \mathrm{~nm}$ adiponectin, with seven of eight expressing both receptor subtypes.

For AP neurons in culture, the changes in membrane potential and action potential frequency usually occurred within 2 min of adiponectin application to the bath (mean of $112 \pm 12 \mathrm{~s}$ ), although latencies ranged from 30 to $240 \mathrm{~s}$. This variation may be partially explained by a large bath volume in some instances. Although the effect of adiponectin could be washed out in some experiments, the effect was frequently long lasting and persisted until the end of the experiment (20-40 min after application). There was no correlation observed with the magnitude or direction of change in membrane potential and the electrophysiological properties of the neuron, such as capacitance, input resistance, presence of $I_{\text {sag }}$, or rate of spontaneous activity, suggesting that the electrophysiological mechanism of the activity of adiponectin activity is complex and involves modulation of multiple ionic conductances.

\section{Single-cell analysis of adiponectin receptor expression}

Our data so far indicated that AP expresses both types of adiponectin receptor and AP neurons are directly affected by adiponectin. Because we observed two types of electrophysiological responses to adiponectin in AP neurons (depolarization and hyperpolarization), we next sought to determine whether the pattern of expression of AdipoR1 and AdipoR2 expression in single neurons correlated with the type of electrophysiological response observed (Fig. 4). To do this, we used patch-clamp electrophysiology followed by single-cell RT-PCR. We first analyzed the sensitivity of 14 AP neurons to $10 \mathrm{~nm}$ adiponectin using currentclamp recording and, after recording, harvested the cytoplasm by negative suction. The RNA in the cytoplasm was used as a tem- plate for cDNA synthesis. The cDNA was subsequently amplified and tested for the presence of AdipoR1 and AdipoR2, as well as the housekeeping genes $\beta$-actin and synaptotagmin-1 using gene-specific primers (Fig. $4 A-C$ ). The results of this analysis are shown in Figure $4 D$. In the 14 cells tested, eight responded to $10 \mathrm{~nm}$ adiponectin with either a depolarization (six of eight) or a hyperpolarization (two of eight), whereas six did not respond. Of the eight cells that responded to adiponectin, seven expressed both AdipoR1 and AdipoR2 (five of six depolarizing cells and two of two hyperpolarizing cells), and one cell expressed only AdipoR1 (a depolarizing cell). In contrast, of the six cells that did not respond, no cells expressed both AdipoR1 and AdipoR2, four cells expressed only AdipoR1, one cell expressed only AdipoR2, and one cell did not express either adiponectin receptor subtype. Collectively, these data indicate that adiponectin-sensitive AP neurons predominantly expressed both AdipoR1 and AdipoR2 subtypes of receptor. Moreover, the observation that eight of eight of the responding neurons expressed AdipoR2 suggests that AdipoR2 is required for cells to exhibit an electrophysiological response.

\section{Response to microinjection of adiponectin}

To determine whether actions of adiponectin at the AP play a physiological role, we next performed in vivo experiments microinjecting adiponectin into acutely exposed AP of urethane-anesthetized rats. Nine animals had histologically confirmed microinjection sites within AP (Fig. 5A). Microinjection of 1 pmol of adiponectin resulted in a clear increase in blood pressure (Fig. 5B), without a significant change in heart rate (Fig. $5 C$ ). To compare the change in blood pressure and heart rate induced by microinjection of adiponectin to control peptide, we calculated the mean AUC for the $300 \mathrm{~s}$ after microinjection. Analysis of blood pressure data revealed that microinjection of adiponectin resulted in a mean AUC of $1617.0 \pm 592.0 \mathrm{mmHg} / \mathrm{s}$ $(n=5)$, which was significantly greater than $-496 \pm 446$ $\mathrm{mmHg} / \mathrm{s}$ observed for microinjection of the control peptide $(n=$ $4 ; p=0.030)$. In contrast, analysis of heart rate data revealed that microinjection of adiponectin into AP resulted in an AUC of $85.9 \pm 40.3$ beats, which was not significantly different from $48.9 \pm 24.9$ beats $(p=0.49)$ observed for microinjection of the control peptide. These blood pressure effects were typically observed within $30 \mathrm{~s}$ of the microinjection and lasted at least $400 \mathrm{~s}$ before returning to baseline. To control for the possibility that the observed increase in blood pressure was attributable to a systemic effect of adiponectin that could have leaked into the circulation during the AP microinjection and had an effect elsewhere, we monitored AUC for blood pressure and heart rate data for $300 \mathrm{~s}$ after intravenous injection of $1 \mathrm{pmol}$ of adiponectin (in $500 \mathrm{nl}$ ) or $500 \mathrm{nl}$ of saline. We did not observe any significant change in blood pressure with intravenous injection of adiponectin (266 \pm $834.2 \mathrm{mmHg} / \mathrm{s})$ compared with saline $(285 \pm 669.2 \mathrm{mmHg} / \mathrm{s})$ ( $n=4 ; p=0.98$, pared $t$ test $)$, nor did we observe any significant 
change in heart rate with intravenous injection of adiponectin $(2.0 \pm 22.6$ beats $)$ compared with saline $(28.9 \pm 25.4$ beats $)$ ( $n=4 ; p=0.49$, paired $t$ test), thus confirming that the observed increase in blood pressure was attributable to an effect on AP neurons.

\section{Discussion}

Our study demonstrates that adiponectin influences AP neurons and may have an important role in cardiovascular regulation based on the following findings: (1) adiponectin receptor mRNA were detected in AP by RT-PCR and in situ hybridization; (2) $\sim 60 \%$ of AP neurons tested were sensitive to adiponectin, exhibiting either a depolarization or hyperpolarization; and (3) microinjection of adiponectin into AP caused a significant increase in blood pressure, whereas microinjection of the collagenous tail fragment had no effect. Furthermore, our work indicates that the effects of adiponectin in AP appear to be mediated by neurons expressing both subtypes of adiponectin receptors.

In the present study, we used electrophysiology to examine the response of individual AP neurons to adiponectin. The observation of both depolarizing and hyperpolarizing effects is consistent with previous studies demonstrating the existence of subpopulations of neurons within the AP that respond differently to specific hormones (Ferguson and Marcus, 1988; Ferguson, 1991; Smith et al., 1994; Cai and Bishop, 1995; Yang and Ferguson, 2002, 2003).

To examine the electrophysiological response of AP neurons to adiponectin, we used an in vitro preparation of dissociated adult neurons maintained in culture for $1-4 \mathrm{~d}$. This ensures that all synaptic input is removed from the neurons and the effects are unquestionably direct. AP neurons in this preparation exhibited membrane properties and patterns of activity similar to those of acutely dissociated neurons prepared by others (Hay et al., 1996) and neurons from acute slices (Jahn et al., 1996; Funahashi et al., 2003; present study). Although cells maintained for longer periods were not used in this study, the observation that these cultured AP neurons can be maintained for several weeks (our unpublished observations) attests to the suitability of these cells. Although it may be possible that culturing of AP neurons may influence expression of adiponectin receptors, experiments performed using AP neurons from acutely prepared brainstem slices indicated that adiponectin caused hyperpolarizing and depolarizing effects in these acutely prepared cells. Therefore, these data argue that the effect of exogenous adiponectin on dissociated AP neurons reflects the physiological signaling of circulating adiponectin.

In the present study, we used RT-PCR and in situ hybridization to examine expression of AdipoR1 and AdipoR2. These experiments demonstrate expression of the two receptor subtypes in AP, which we confirmed in preliminary experiments with Western blots (data not shown). Unfortunately, however, immunohistochemistry with several commercial antibodies could not produce satisfactory results to identify expression of AdipoR1 and AdipoR2. Because the whole AP RT-PCR and in situ hybridizations (Fig. 1) were not quantitative and could not demonstrate neuronal expression, we used patch-clamp analysis followed by single-cell RT-PCR on neurons in a manner similar to that de-

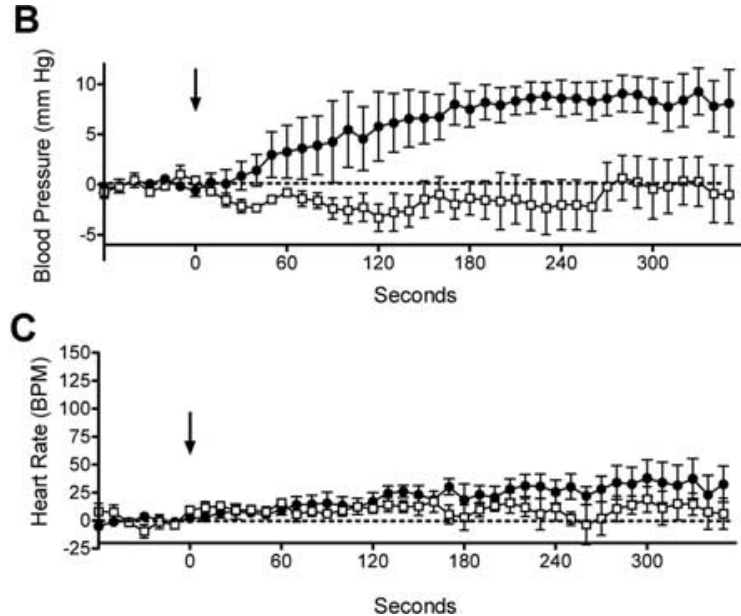

Seconds

Figure 5. Microinjection of adiponectin into AP results in an increase in blood pressure but not heart rate. $\boldsymbol{A}$, Photomicrograph the location of adiponectin injections (black circles indicate adiponectin sites, and white squares indicate control iponectin $(n=5)$ and control peptide $(n=4)$. Symbols are as in $\boldsymbol{A}$. Arrow indicates time of injection. $\boldsymbol{C}$, Mean normalized heart rate after 5) and control peptide $(n=4)$. Symbols are as in A. Arrow indicates time of injection.

scribed previously (Dixon et al., 1998; Richardson et al., 2000; van den Top et al., 2004) A key concern with using small amounts of template for RT-PCR is the possibility of false-positive and falsenegative results. To eliminate the possibility that the observed RT-PCR signals were the result of amplification of contaminating genomic DNA, RNA samples were first treated with DNase I (see Materials and Methods). In addition, several control reactions were included with every experiment: we always performed a cDNA synthesis reaction using circulating bath solution; also, an RT minus control reaction was performed using a harvested cell, but omitting the reverse transcriptase enzyme from the reaction. We also performed no-template PCR reactions. These always produced negative results, indicating the absence of contamination. To reduce the possibility of false-negative results, we performed RT-PCR for two housekeeping genes, $\beta$-actin and synaptotagmin-1, to ensure that mRNA harvest and cDNA synthesis after electrophysiological recording was successful and that a lack of signal for AdipoR1 or AdipoR2 reflected patterns of gene expression, not a suboptimal RT-PCR reaction. Therefore, we are confident that the single-cell RT-PCR results reflect gene expression at the time of harvest.

These experiments also provide new insight into the functionality of AdipoR1 and AdipoR2 within the AP. Our experiments combining patch-clamp electrophysiology and single-cell RTPCR indicate that 13 of 14 neurons expressed at least one subtype of adiponectin receptor. Moreover, AP neurons that are sensitive to adiponectin predominantly express both subtypes of receptor, whereas insensitive neurons predominantly express only one subtype. Although, as in any electrophysiology experiment, it is possible that the choosing of "ideal" cells for analysis (smooth surface, compact shape, phase-bright appearance, absence of contacts from other cells, etc.) may exclude some cells, we believe the present results examining gene expression in 14 neurons indicate that coexpression of the two subtypes of receptor in neurons results in effective adiponectin signaling in AP neurons. Although the relative abundance of AdipoR1 in skeletal muscle and AdipoR2 in liver suggests that the two subtypes can act independently, it is possible that AdipoR1 and AdipoR2 may form functional heteromultimeric signaling complexes. Indeed, it is well accepted that many G-protein coupled receptors (GPCR) 
form dimers and heteromeric complexes, and recent evidence suggests that some GPCRs may form heteromers with novel properties (Milligan, 2004). The possibility that AdipoR1 and AdipoR2 (which are non-GPCRs) also form heteromultimers in neurons deserves additional investigation.

The AP is well known to act as a homeostatic integration center involved in cardiovascular regulation (Joy and Lowe, 1970; Ylitalo et al., 1974; Ferguson, 1991; Bishop and Hay, 1993). Therefore, the observation that many AP neurons were sensitive to adiponectin is consistent with our observations that exogenous adiponectin acts in AP to influence cardiovascular function. Interestingly, previous experiments revealed that microinjection of lower and moderate doses of vasopressin and angiotensin II into AP have resulted in significant increases in blood pressure without increases in heart rate (Lowes et al., 1993). This similarity raises the question of whether regulation of blood pressure by vasopressin, angiotensin, and adiponectin might occur via the same network of neurons in the AP.

The magnitude of the increase in blood pressure we observed during microinjection of adiponectin in AP was similar to that observed for microinjection of other vasoactive peptide hormones into AP, including vasopressin, angiotensin, adrenomedullin, and endothelin (Ferguson and Smith, 1990; Lowes et al., 1993; Allen et al., 1997). The observation that microinjection of adiponectin in AP caused an increase in blood pressure might seem at first paradoxical: given that low levels of peripherally circulating adiponectin are associated with hypertension, one might expect a depressor response. However, contrasting cardiovascular responses have been observed for other vasoactive peptides, such as endothelin (Yanagisawa et al., 1988; Ferguson and Smith, 1990) and adrenomedullin (Kitamura et al., 1995; Allen et al., 1997), when administered centrally compared with peripherally. The seemingly paradoxical response may well reflect a feedback mechanism regulating the cardiovascular control system. These data are consistent with previous reports suggesting subpopulations of neurons that target centers modulating blood pressure but not heart rate (Ferguson and Marcus, 1988).

Although Qi et al. (2004) suggested that adiponectin can move from the blood to directly activate hypothalamic paraventricular neurons (PVNs) and cause insulin-sensitizing actions, others suggest adiponectin cannot cross the BBB (Pan et al., 2006; Spranger et al., 2006). We hypothesized that, because AP lacks a $\mathrm{BBB}$ and is well known to detect other circulating hormones, adiponectin may act directly on AP neurons to exert homeostatic control. Our observations that microinjection of adiponectin into AP caused changes in blood pressure indicates that AP is indeed a key site of adiponectin action within the CNS. Several studies have associated low levels of circulating adiponectin with hypertension in human patients (Adamczak et al., 2003; Iwashima et al., 2004; Wakabayashi and Aso, 2004), but this study is the first to directly show that injection of adiponectin can modulate cardiovascular function, thereby providing a possible mechanism for the association between development of obesity and hypertension. Control experiments microinjecting the inactive C-terminal portion of the protein indicate the specificity of AP in this pathway.

In summary, we have shown that individual AP neurons are sensitive to adiponectin and that adiponectin can act at AP to modulate blood pressure, demonstrating that circulating adiponectin can influence cardiovascular regulation in addition to energy homeostasis. That adiponectin can activate PVNs (Qi et al., 2004) and influence at least two populations of AP neurons (ones that depolarize and ones that hyperpolarize) indicates that the response to adiponectin in the CNS is complex. Elucidation of the neural pathways involved in adiponectin signaling may provide a basis of understanding for the prevention and treatment of obesity and obesity-related diseases.

\section{References}

Adamczak M, Wiecek A, Funahashi T, Chudek J, Kokot F, Matsuzawa Y (2003) Decreased plasma adiponectin concentration in patients with essential hypertension. Am J Hypertens 16:72-75.

Ahima RS, Kelly J, Elmquist JK, Flier JS (1999) Distinct physiologic and neuronal responses to decreased leptin and mild hyperleptinemia. Endocrinology 140:4923-4931.

Allen MA, Smith PM, Ferguson AV (1997) Adrenomedullin microinjection into the area postrema increases blood pressure. Am J Physiol 272:R1698-R1703.

Berg AH, Combs TP, Du X, Brownlee M, Scherer PE (2001) The adipocytesecreted protein Acrp30 enhances hepatic insulin action. Nat Med 7:947-953.

Bishop VS, Hay M (1993) Involvement of the area postrema in the regulation of sympathetic outflow to the cardiovascular system. Front Neuroendocrinol 14:57-75.

Brewer GJ (1997) Isolation and culture of adult rat hippocampal neurons. J Neurosci Methods 71:143-155.

Cai Y, Bishop VS (1995) Effects of arginine vasopressin and angiotensin II on area postrema neurons in rabbit brain slice preparation. Neurosci Lett 190:125-128.

Combs TP, Berg AH, Obici S, Scherer PE, Rossetti L (2001) Endogenous glucose production is inhibited by the adipose-derived protein Acrp30. J Clin Invest 108:1875-1881.

Combs TP, Pajvani UB, Berg AH, Lin Y, Jelicks LA, Laplante M, Nawrocki AR, Rajala MW, Parlow AF, Cheeseboro L, Ding YY, Russell RG, Lindemann D, Hartley A, Baker GR, Obici S, Deshaies Y, Ludgate M, Rossetti L, Scherer PE (2004) A transgenic mouse with a deletion in the collagenous domain of adiponectin displays elevated circulating adiponectin and improved insulin sensitivity. Endocrinology 145:367-383.

Cottrell GT, Ferguson AV (2004) Sensory circumventricular organs: central roles in integrated autonomic regulation. Regul Pept 117:11-23.

Damcott CM, Ott SH, Pollin TI, Reinhart LJ, Wang J, O'connell JR, Mitchell BD, Shuldiner AR (2005) Genetic variation in adiponectin receptor 1 and adiponectin receptor 2 is associated with type 2 diabetes in the Old Order Amish. Diabetes 54:2245-2250.

Dixon AK, Richardson PJ, Lee K, Carter NP, Freeman TC (1998) Expression profiling of single cells using 3 prime end amplification (TPEA) PCR. Nucleic Acids Res 26:4426-4431.

Ferguson AV (1991) The area postrema: a cardiovascular control centre at the blood-brain interface? Can J Physiol Pharmacol 69:1026-1034.

Ferguson AV, Marcus P (1988) Area postrema stimulation induced cardiovascular changes in the rat. Am J Physiol 255:R855-R860.

Ferguson AV, Smith P (1990) Cardiovascular responses induced by endothelin microinjection into area postrema. Regul Pept 27:75-85.

Funahashi M, Mitoh Y, Kohjitani A, Matsuo R (2003) Role of the hyperpolarization-activated cation current (Ih) in pacemaker activity in area postrema neurons of rat brain slices. J Physiol (Lond) 552:135-148.

Hara K, Yamauchi T, Kadowaki T (2005) Adiponectin: an adipokine linking adipocytes and type 2 diabetes in humans. Curr Diab Rep 5:136-140.

Hay M, Hasser EM, Lindsley KA (1996) Area postrema voltage-activated calcium currents. J Neurophysiol 75:133-141.

Iwashima Y, Katsuya T, Ishikawa K, Ouchi N, Ohishi M, Sugimoto K, Fu Y, Motone M, Yamamoto K, Matsuo A, Ohashi K, Kihara S, Funahashi T, Rakugi H, Matsuzawa Y, Ogihara T (2004) Hypoadiponectinemia is an independent risk factor for hypertension. Hypertension 43:1318-1323.

Jahn K, Bufler J, Weindl A, Arzberger T, Hatt H (1996) Patch-clamp study on membrane properties and transmitter activated currents of rabbit area postrema neurons. J Comp Physiol A Neuroethol Sens Neural Behav Physiol 178:771-778.

Joy MD, Lowe RD (1970) Evidence that the area postrema mediates the central cardiovascular response to angiotensin II. Nature 228:1303-1304

Jung TW, Lee JY, Shim WS, Kang ES, Kim JS, Ahn CW, Lee HC, Cha BS (2006) Adiponectin protects human neuroblastoma SH-SY5Y cells against MPP+-induced cytotoxicity. Biochem Biophys Res Commun 343:564-570. 
Kadowaki T, Yamauchi T (2005) Adiponectin and adiponectin receptors. Endocr Rev 26:439-451.

Kelly JF, Elias CF, Lee CE, Ahima RS, Seeley RJ, Bjorbaek C, Oka T, Saper CB, Flier JS, Elmquist JK (2004) Ciliary neurotrophic factor and leptin induce distinct patterns of immediate early gene expression in the brain. Diabetes 53:911-920.

Kitamura K, Kangawa K, Matsuo H, Eto T (1995) Adrenomedullin. Implications for hypertension research. Drugs 49:485-495.

Kondo H, Shimomura I, Matsukawa Y, Kumada M, Takahashi M, Matsuda M, Ouchi N, Kihara S, Kawamoto T, Sumitsuji S, Funahashi T, Matsuzawa Y (2002) Association of adiponectin mutation with type 2 diabetes: a candidate gene for the insulin resistance syndrome. Diabetes 51:2325-2328.

Kubota N, Terauchi Y, Yamauchi T, Kubota T, Moroi M, Matsui J, Eto K, Yamashita T, Kamon J, Satoh H, Yano W, Froguel P, Nagai R, Kimura S, Kadowaki T, Noda T (2002) Disruption of adiponectin causes insulin resistance and neointimal formation. J Biol Chem 277:25863-25866.

Lowes VL, McLean LE, Kasting NW, Ferguson AV (1993) Cardiovascular consequences of microinjection of vasopressin and angiotensin II in the area postrema. Am J Physiol 265:R625-R631.

Maeda N, Shimomura I, Kishida K, Nishizawa H, Matsuda M, Nagaretani H, Furuyama N, Kondo H, Takahashi M, Arita Y, Komuro R, Ouchi N, Kihara S, Tochino Y, Okutomi K, Horie M, Takeda S, Aoyama T, Funahashi T, Matsuzawa Y (2002) Diet-induced insulin resistance in mice lacking adiponectin/ACRP30. Nat Med 8:731-737.

McKinley MJ, McAllen RM, Davern P, Giles ME, Penschow J, Sunn N, Uschakov A, Oldfield BJ (2003) The sensory circumventricular organs of the mammalian brain. Adv Anat Embryol Cell Biol 172:III-XII, 1-122.

Milligan G (2004) G protein-coupled receptor dimerization: function and ligand pharmacology. Mol Pharmacol 66:1-7.

Pan W, Tu H, Kastin AJ (2006) Differential BBB interactions of three ingestive peptides: obestatin, ghrelin, and adiponectin. Peptides 27:911-916.

Prins JB (2002) Adipose tissue as an endocrine organ. Best Pract Res Clin Endocrinol Metab 16:639-651.

Qi Y, Takahashi N, Hileman SM, Patel HR, Berg AH, Pajvani UB, Scherer PE, Ahima RS (2004) Adiponectin acts in the brain to decrease body weight. Nat Med 10:524-529.

Richardson PJ, Dixon AK, Lee K, Bell MI, Cox PJ, Williams R, Pinnock RD, Freeman TC (2000) Correlating physiology with gene expression in striatal cholinergic neurones. J Neurochem 74:839-846.

Scherer PE, Williams S, Fogliano M, Baldini G, Lodish HF (1995) A novel serum protein similar to $\mathrm{C} 1 \mathrm{q}$, produced exclusively in adipocytes. J Biol Chem 270:26746-26749.
Smith PM, Lowes VL, Ferguson AV (1994) Circulating vasopressin influences area postrema neurons. Neuroscience 59:185-194.

Spranger J, Verma S, Gohring I, Bobbert T, Seifert J, Sindler AL, Pfeiffer A, Hileman SM, Tschop M, Banks WA (2006) Adiponectin does not cross the blood-brain barrier but modifies cytokine expression of brain endothelial cells. Diabetes 55:141-147.

Ukkola O, Santaniemi M (2002) Adiponectin: a link between excess adiposity and associated comorbidities? J Mol Med 80:696-702.

van den Top M, Lee K, Whyment AD, Blanks AM, Spanswick D (2004) Orexigen-sensitive NPY/AgRP pacemaker neurons in the hypothalamic arcuate nucleus. Nat Neurosci 7:493-494.

Wakabayashi S, Aso Y (2004) Adiponectin concentrations in sera from patients with type 2 diabetes are negatively associated with sympathovagal balance as evaluated by power spectral analysis of heart rate variation. Diabetes Care 27:2392-2397.

Yamauchi T, Kamon J, Waki H, Terauchi Y, Kubota N, Hara K, Mori Y, Ide T, Murakami K, Tsuboyama-Kasaoka N, Ezaki O, Akanuma Y, Gavrilova O, Vinson C, Reitman ML, Kagechika H, Shudo K, Yoda M, Nakano Y, Tobe $\mathrm{K}$, et al. (2001) The fat-derived hormone adiponectin reverses insulin resistance associated with both lipoatrophy and obesity. Nat Med 7:941-946.

Yamauchi T, Kamon J. Ito Y, Tsuchida A, Yokomizo T, Kita S, Sugiyama T, Miyagishi M, Hara K, Tsunoda M, Murakami K, Ohteki T, Uchida S, Takekawa S, Waki H, Tsuno NH, Shibata Y, Terauchi Y, Froguel P, Tobe $\mathrm{K}$, et al. (2003) Cloning of adiponectin receptors that mediate antidiabetic metabolic effects. Nature [Erratum 431:1123] 23:762-769.

Yanagisawa M, Inoue A, Ishikawa T, Kasuya Y, Kimura S, Kumagaye S, Nakajima K, Watanabe TX, Sakakibara S, Goto K (1988) Primary structure, synthesis, and biological activity of rat endothelin, an endotheliumderived vasoconstrictor peptide. Proc Natl Acad Sci USA 85:6964-6967.

Yang B, Ferguson AV (2002) Orexin-A depolarizes dissociated rat area postrema neurons through activation of a nonselective cationic conductance. J Neurosci 22:6303-6308.

Yang B, Ferguson AV (2003) Adrenomedullin influences dissociated rat area postrema neurons. Regul Pept 112:9-17.

Yang B, Brown KK, Chen L, Carrick KM, Clifton LG, McNulty JA, Winegar DA, Strum JC, Stimpson SA, Pahel GL (2004) Serum adiponectin as a biomarker for in vivo PPARgamma activation and PPARgamma agonistinduced efficacy on insulin sensitization/lipid lowering in rats. BMC Pharmacol 4:23.

Ylitalo P, Karppanen H, Paasonen MK (1974) Is the area postrema a control center of blood pressure? Nature 247:58-59. 